\title{
Three new species of bristletails of the families Meinertellidae and Machilidae (Archaeognatha) from Ukraine and Southern Russia
}

\author{
Vladimir KAPLIN ${ }^{1)}$ \& Vladimir MARTYNOV ${ }^{2}$ \\ 1) Al-Russian Institute of Plant Protection, Podbelsky Highway 3, St. Petersburg-Pushkin 196608, Russia; \\ e-mail: ctenolepisma@mail.ru (corresponding author) \\ ${ }^{2)}$ Donetsk Botanical Garden, Illich’s Avenue 110, Donetsk 83059, Ukraine; e-mail: martynov.scarab@yandex.ua
}

Accepted:

$16^{\text {th }}$ July 2020

Published online: $5^{\text {th }}$ August 2020

\begin{abstract}
Two new species of Machilinus Silvestri, 1905 (M. petrophilus Kaplin, sp. nov., M. obscurus Kaplin, sp. nov.) from Ukraine and one new species of Charimachilis Wygodzinsky, 1939 (C. rostoviensis Kaplin sp. nov.) from Southern Russia are described. The new species of Machilinus belong to the subgenus Machilinus s. str. with $1+1$ eversible vesicles on urocoxites II-VII, and urostyli with apical spines; to the group "rupestris" with $2^{\text {nd }}$ and $3^{\text {rd }}$ articles of male maxillary palpus without ventral spines (M. obscurus sp. nov.), and with spines on these articles (M. petrophilus sp. nov.). Machilinus petrophilus sp. nov. differs from M. rocai Bach, 1975 in the color and ratio of length to width of compound eyes, the presence of numerous short chaetae on the clypeus, the structure of the lateral apophysis on the $2^{\text {nd }}$ article of the male maxillary palpus, and the number of ventral spines on the legs. Machilinus obscurus sp. nov. differs from the other species of the group "rupestris" in the color of compound eyes, the presence of numerous short chaetae on the male frons and clypeus, and in other features. Charimachilis rostoviensis sp. nov. (Machilidae) most closely resembles $C$. ukrainensis Stach, 1958. Charimachilis rostoviensis sp. nov. differs from C. ukrainensis in the shape of posterior angle of urosternites, and ratios of lengths of urostyli and urocoxites.
\end{abstract}

Key words. Archaeognatha, Microcoryphia, Meinertellidae, Machilidae, Machilinus, Charimachilis, new species, taxonomy, Russia, Ukraine, Palaearctic Region

Zoobank: http://zoobank.org/urn:lsid:zoobank.org:pub:D44E89D9-9DD5-4B50-BF58-D38E371E0692

(C) 2020 The Authors. This work is licensed under the Creative Commons Attribution-NonCommercial-NoDerivs 3.0 Licence

\section{Introduction}

The fauna of Archaeognatha (= Microcoryphia) bristletails of Ukraine and Southern Russia has almost not been studied and includes only five species: Charimachilis ukrainensis Stach, 1958 (Kiev and its vicinity, the bank of the Dnieper River), C. morozovi Kaplin, 2019 (Belgorod region, Shebekinsky district, cretaceous rock outcrops), Allopsonts europeus (Kaplin, 1983), Petrobius crimaeus Kaplin, 1983 (Machilidae), and Machilinus sp. (Meinertellidae) (Crimea, Crimean mountains) (STACH 1958; KAPLIN 1983, 2019). Examination of bristletails collected by V. Martynov in Donetsk region (Ukraine) and in Rostov region (Russia) in June, July and September 2019 revealed two new species of the genus Machilinus Silvestri, 1905 (Meinertellidae) and one species of the genus Charimachilis Wygodzinsky, 1939 (Machilidae) which are described in the present work.

\section{Materials and methods}

The specimens of bristletails were collected under stones (Machilinus) or under dead pine trunks (Charimachilis) and were preserved in 70\% ethanol. The holotypes and some paratypes are mounted in Faure's solution on permanent microscopic slides, and the remaining paratypes are preserved in $70 \%$ ethanol. The specimens studied are deposited in the collection of the Zoological Institute, Russian Academy of Sciences, St. Petersburg (ZIN). 


\section{Taxonomy}

Family Meinertellidae

Machilinus petrophilus Kaplin, sp. nov.

(Figs 1-3)

Type material. HoLOTYPE: (slide-mounted, ZIN), UKRAINE:

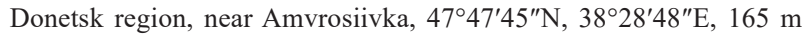
a.s.l., scree of lime marl, petrophytic steppe, under stones, September 24, 2019, V. Martynov leg. PARATYPE: ㅇ (on slides), the same locality, V. Martynov leg. (ZIN).

Description. Body length: male $6.6 \mathrm{~mm}$, female $6.5 \mathrm{~mm}$. Body width: male $1.9 \mathrm{~mm}$, female $2.0 \mathrm{~mm}$. Antennal length: male $4.8 \mathrm{~mm}$, female $4.0 \mathrm{~mm}$ (broken); cercal length 1.8 $\mathrm{mm}$ in male, $2.6 \mathrm{~mm}$ in female; total eyes width: $0.89 \mathrm{~mm}$ in male, $0.88 \mathrm{~mm}$ in female; eye length: $0.53 \mathrm{~mm}$ in male, female $0.59 \mathrm{~mm}$ in female; paired ocelli width: male and female $0.16 \mathrm{~mm}$ in both sexes; paired ocelli length: $0.11 \mathrm{~mm}$ in both sexes. Ovipositor length: $3.2 \mathrm{~mm}$. Thoracic coxal styli absent. Head including antennae, maxillary and labial palpi, clypeus, labrum, labium and legs without scales.

General body color whitish, with hypodermal pigment. Antennal base, occiput, frons, gena, lateral sides of clypeus, labrum, labium, maxillae, mandibles, maxillary and labial palpi, antennae, legs, thorax, abdominal tergites and sternites with purple-brown hypodermal pigment of medium to high intensity. Color of body scales brown. Antennae of male and female shorter than body. Ratio of length to width of scapus about 2.2 in male and 1.9 in female (Fig. 1A). Distal chains of flagellum divided into 8-9 annuli in both sexes. Two or three distal chains of antennal flagellum broken. Clypeus of both sexes with relatively numerous short simple chaetae (Fig. 1B). Front half of female clypeus with numerous dark small chaetae. Cercus in male and female approximately 0.27 times and 0.40 times as long as body length, respectively. Apex of cercus with one large lateral spike (Fig. 1C). Second lateral spike smaller and broken. Each division of cercus with two or four rows of scales. Divisions of cerci, except for apical one, with one to three supporting spines on inner side.

Compound eyes bicolor light gray with brown speckles (in ethanol). Ratio of length to width of compound eye about 1.2 in male and 1.3 in female; ratio of contact line length to eye length 0.70 in male and 0.76 in female. Paired ocelli oval, sublateral, white, 1.5 times as wide as long in male and 1.4 times in female. Distance between inner margins of ocelli $0.68-0.70$ and between their outer margins $0.96-0.98$ of total width of compound eyes in both sexes (Fig. 1B).

Apical article of maxillary palpus in both sexes 0.56 0.63 times as long as preceding one. Dorsal surface of $7^{\text {th }}$, $6^{\text {th }}$ and $5^{\text {th }}$ articles of maxillary palpus with 10,9 or 10 , and 1 hyaline spines in male, and 10 or 11,11 or 12 , and 3 or 4 spines in female, respectively (Fig. 1D). $5^{\text {th }}$ article of maxillary palpus about 1.67 times as long as $4^{\text {th }}$ article in male and 1.45-1.50 times in female. Second article of male maxillary palpus noticeably curved with external lateral apical apophysis (Fig. 1E), but absent in female maxillary palpus. Apophysis far surpassing distal end of second article. Ventral part of apophysis and adjacent part of $2^{\text {nd }}$ article with about 12-15 dark, almost black, short spiniform chaetae (spines). $3^{\text {rd }}$ article of male maxillary palpus also with about 25 almost black short lateral spines (Fig. 1E). Dorsal and lateral surface of $1^{\text {st }}, 2^{\text {nd }}$ and $3^{\text {rd }}$ articles of male maxillary palpus with numerous relatively long thickened macrochaetae. Apical article of labial palpus triangularly oval, 3.8 times as long as wide in male and 3.2 times in female (Figs 1F-H). Apical article of male labial palpus without sexual dimorphism. Space occupied by distal connuli of third article of labial palpus well developed. Ratio

Table 1. Ratios of lengths to widths of main leg articles in Machilinus petrophilus sp. nov.

\begin{tabular}{llcc}
\hline \multirow{2}{*}{ Leg articles } & & \multicolumn{2}{c}{ Sex } \\
\cline { 3 - 4 } Tarsus & fore & $5.36-5.50$ & $4.78-5.08$ \\
& middle & $4.75-5.27$ & $4.72-4.92$ \\
& hind & $6.03-6.38$ & $5.95-6.05$ \\
\hline \multirow{3}{*}{ Tibia } & fore & 2.06 & 1.96 \\
& middle & $2.37-2.58$ & $2.00-2.46$ \\
& hind & $3.12-3.15$ & $3.17-3.36$ \\
\hline \multirow{3}{*}{ Femur } & fore & $1.96-2.00$ & $1.93-1.94$ \\
& middle & $2.49-2.76$ & $2.69-2.84$ \\
& hind & $2.64-2.78$ & $2.98-3.04$ \\
\multirow{2}{*}{ Coxa } & fore & $2.68-2.70$ & $2.20-2.23$ \\
& middle & $2.53-2.58$ & $2.92-2.94$ \\
& hind & $2.88-2.92$ & $2.95-3.09$ \\
\hline
\end{tabular}

Table 2. Number of spines on legs in Machilinus petrophilus sp. nov.

\begin{tabular}{|c|c|c|c|c|c|c|c|}
\hline \multirow{3}{*}{ Segments } & & \multicolumn{6}{|c|}{ Sex and pair of legs } \\
\hline & & \multicolumn{3}{|c|}{ Male } & \multicolumn{3}{|c|}{ Female } \\
\hline & & fore & middle & hind & fore & middle & hind \\
\hline \multirow{3}{*}{ Tarsomeres } & $1^{\text {st }}$ & 5 & 12 & 10 & 5 & $6-10$ & 11 \\
\hline & $2^{\text {nd }}$ & $12-13$ & 12 & $13-14$ & 10 & $8-9$ & $8-10$ \\
\hline & $3^{\text {rd }}$ & 9 & 9 & 10 & $8-10$ & $9-10$ & $8-9$ \\
\hline \multicolumn{2}{|l|}{ Tibia } & $8-9$ & $13-14$ & $24-25$ & $8-9$ & $10-11$ & 21 \\
\hline \multicolumn{2}{|l|}{ Femur } & $7-8$ & $16-17$ & $13-14$ & $8-10$ & $17-18$ & $11-12$ \\
\hline
\end{tabular}

Table 3. Ratios of lengths of some abdominal structures in Machilinus petrophilus sp. nov. Apical spines are not included in stylus length.

\begin{tabular}{|c|c|c|c|c|c|c|c|c|}
\hline \multirow[t]{2}{*}{$\begin{array}{l}\text { Uri- } \\
\text { tes }\end{array}$} & \multicolumn{2}{|c|}{$\begin{array}{l}\text { Urosternite / } \\
\text { urocoxite }\end{array}$} & \multicolumn{2}{|c|}{$\begin{array}{l}\text { Stylus / } \\
\text { urocoxite }\end{array}$} & \multicolumn{2}{|c|}{$\begin{array}{c}\text { Apical spine / } \\
\text { stylus }\end{array}$} & \multicolumn{2}{|c|}{$\begin{array}{l}\text { Posterior angle } \\
\text { of urosternite }\end{array}$} \\
\hline & male & female & male & female & male & female & male & female \\
\hline I & 0.21 & 0.23 & - & - & - & - & $134^{\circ}$ & $141^{\circ}$ \\
\hline II & 0.22 & 0.27 & 0.70 & 0.68 & 0.32 & 0.28 & $136^{\circ}$ & $140^{\circ}$ \\
\hline III & 0.24 & 0.23 & 0.63 & 0.63 & 0.33 & 0.36 & $133^{\circ}$ & $140^{\circ}$ \\
\hline IV & 0.23 & 0.23 & 0.61 & 0.61 & 0.33 & 0.36 & $142^{\circ}$ & $147^{\circ}$ \\
\hline V & 0.17 & 0.22 & 0.53 & 0.62 & 0.42 & 0.35 & $162^{\circ}$ & $145^{\circ}$ \\
\hline VI & 0.14 & 0.15 & 0.53 & 0.56 & 0.36 & 0.38 & $162^{\circ}$ & $157^{\circ}$ \\
\hline VII & 0.13 & 0.13 & 0.52 & 0.54 & 0.38 & 0.37 & $169^{\circ}$ & $160^{\circ}$ \\
\hline VIII & 0.07 & - & 0.67 & 0.84 & 0.38 & 0.30 & $172^{\circ}$ & - \\
\hline IX & - & - & 0.61 & 0.70 & 0.24 & 0.18 & - & - \\
\hline
\end{tabular}

Table 4. Distribution of sublateral mesochaetae and relatively thin chaetae on urocoxites in Machilinus petrophilus sp. nov.

\begin{tabular}{lcc}
\hline \multirow{2}{*}{ Urites } & \multicolumn{2}{c}{ Urocoxites } \\
\cline { 2 - 3 } & Male & Female \\
\hline I & 0 & 0 \\
II & $\approx(25+25)$ & $\approx(25+25)$ \\
III & $\approx(20+20)$ & $\approx(26+26)$ \\
IV & $13-14+13-14$ & $\approx(25+25)$ \\
V & $6-7+6-7$ & $\approx(25+25)$ \\
VI & $6-7+6-7$ & $4-6+4-6$ \\
VII & $1-2+1-2$ & $1-2+1-2$ \\
VIII & $3-4+3-4$ & $2+2$ \\
IX & $2-3 / 8+8 / 2-3$ & $3 /\left(8^{*}+6\right)+\left(6^{*}+8\right) / 2$ \\
\hline
\end{tabular}

* Relatively short pigmented macrochaetae. 


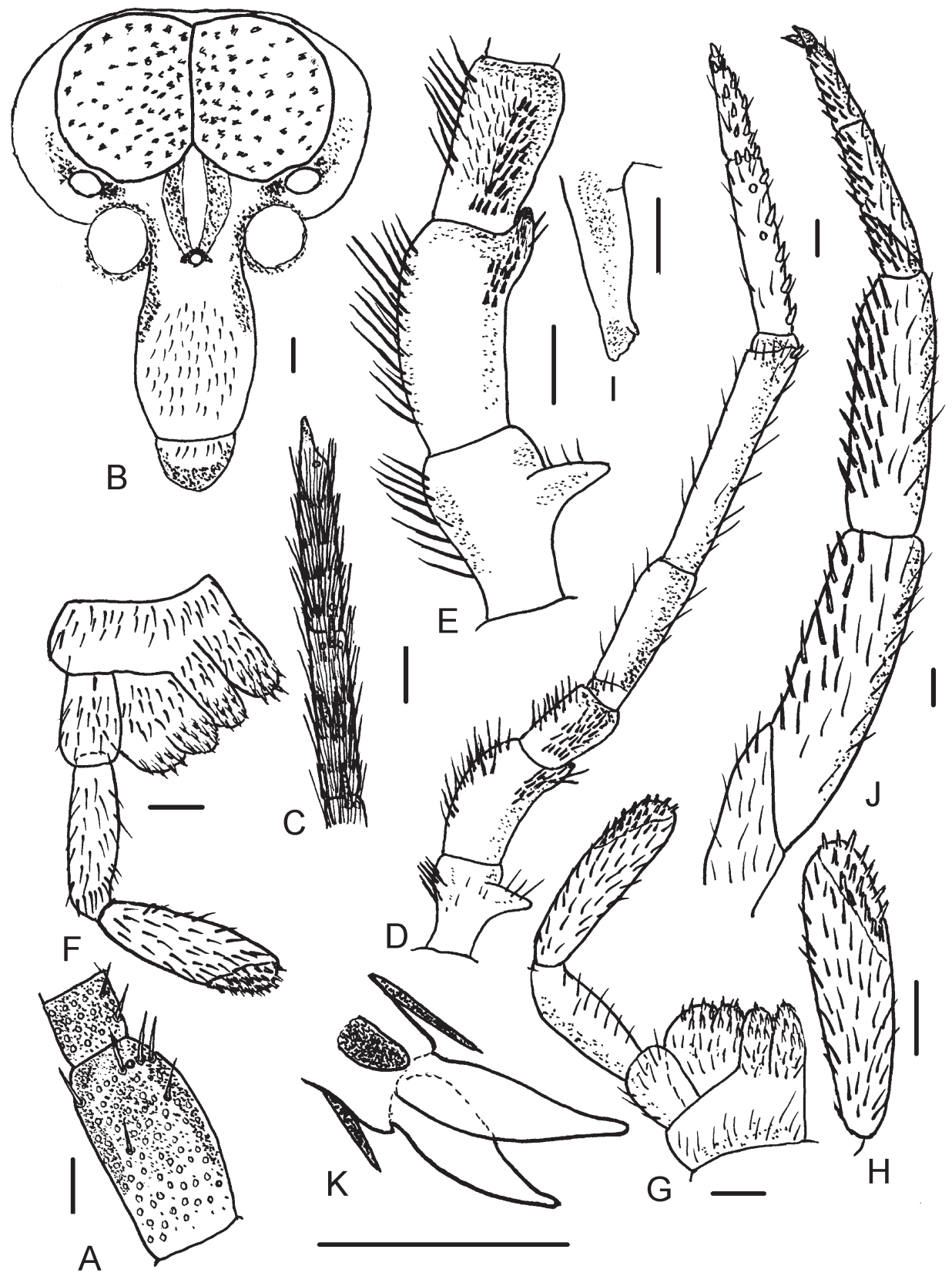

Fig. 1. Machilinus petrophilus sp. nov. (B, D, E, G-K - male, holotype; A, C, F - female, paratype): A - scapus and pedicellus of antenna; B - head, frontal view; $\mathrm{C}$ - distal part of cercus; $\mathrm{D}$ - maxillary palpus; $\mathrm{E}-1^{\text {st }-3^{\text {rd }}}$ articles of maxillary palpus; $\mathrm{F}, \mathrm{G}$ - labial palpus and labium (part); $\mathrm{H}$ - apical article of labial palpus; I - distal part of mandible; J - part of hind leg; $\mathrm{K}$ - pretarsus of hind leg. Scale bar: $0.1 \mathrm{~mm}$.

of lengths of this space and apical article of labial palpus about $0.40-0.42$. Distal part of mandibles with two teeth in both sexes (Fig. 1I).

Fore femur and tibia of male and female widened. Ratios of lengths to widths of coxa, femur, tibia and tarsus as shown in Table 1. Ratio of length of $3^{\text {rd }}$ tarsomere to total length of tarsus $0.36-0.37$ in male and $0.40-0.41$ in female (Fig. 1J). Legs of male without long thin chaetae. Ventral surface of femora, tibiae and tarsi with spines as shown in Table 2. Pretarsi with well-developed conical strongly pigmented support protrusion (Fig. 1K).

In both sexes, abdominal segments II-VII with $1+1$ eversible vesicles (Figs 2A, B). Posterior angle of urosternites more than $130^{\circ}$ (Table 3 ). Ratios of lengths of uros- ternite, stylus (without apical spine) and urocoxites I-IX as shown in Table 3. Inner posterior lobes of urocoxites VII of female protruding (Fig. 2C); ratio of length to their total width about 0.39 .

Pronotum as shown in Fig. 2D. Inner margins of its lateral expansions with about $20+20$ macrochaetae in male and $11+11$ in female. Lateral margins of mesonotum with 50-60 + 50-60, metanotum with 25-30 + 25-30 macrochaetae in both sexes. Lateral parts of mesonotum and sublateral parts of metanotum also with numerous long and thin chaetae in both sexes. Anterior part of urotergite I with 5-7 + 5-7 sublateral chaetae (Fig. 2E), urotergites II-X without chaetae in both sexes. Anterior part of urocoxites I with 7-9 + 7-9 chaetae in both sexes. Distribution of 


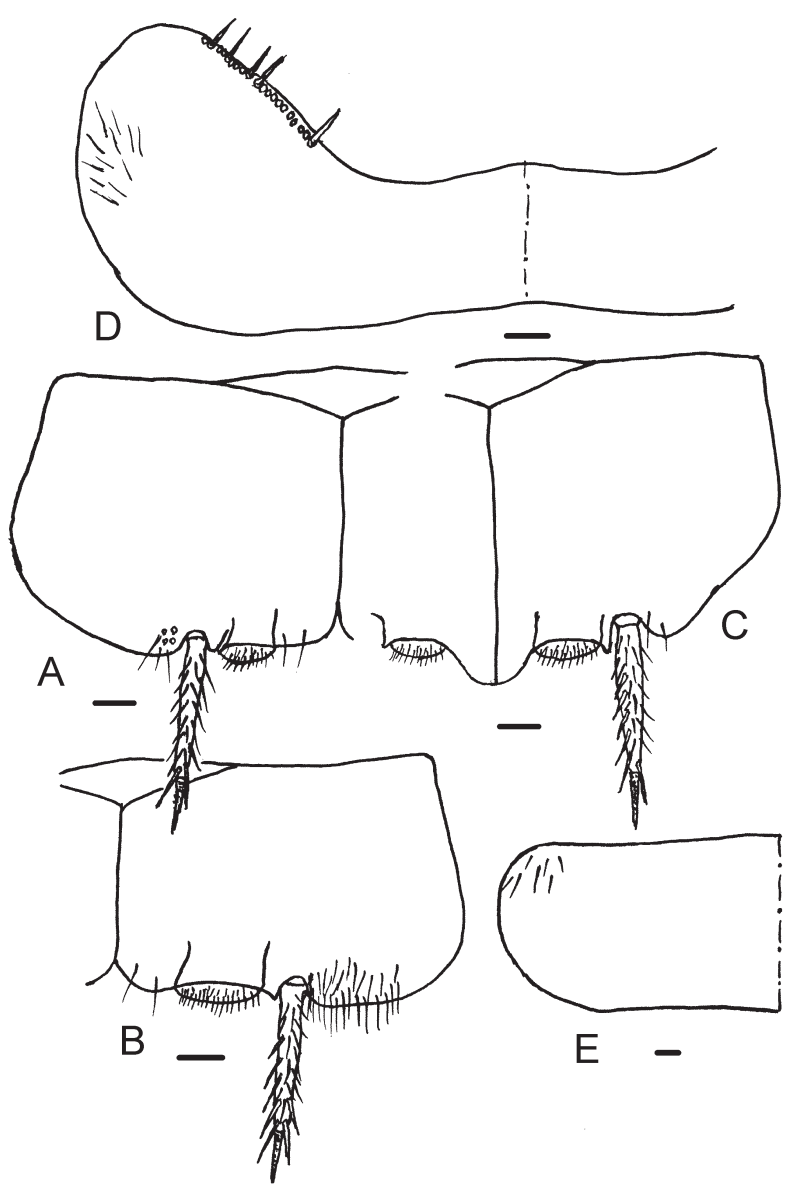

Fig. 2. Machilinus petrophilus sp. nov. (A, D - male, holotype; B, C, $\mathrm{E}$ - female, paratype): A, B - urosternite and urocoxites $\mathrm{V}$ (part); C urosternite and urocoxites VII (part); D - pronotum (part); E- urotergite I (part). Scale bar: $0.1 \mathrm{~mm}$.

sublateral chaetae on urocoxites II-IX as shown in Table 4.

Ovipositor slender, elongate, extending much further than apex of styli IX. Anterior and posterior gonapophyses with 68 and 70 divisions, respectively (Figs 3A, B). Two basal divisions of anterior gonapophyses and about 29 proximal divisions of posterior gonapophyses glabrous. Apical divisions of anterior and posterior gonapophyses with five or six chaetae (not counting sensory chaetae and apical spines) (Figs C, D). Distal divisions of anterior and posterior gonapophyses with long chaetae as shown in Figs 3A, B. Apical spines of gonapophyses as long as 2.6-3.0 apical divisions combined (Figs 3C, D).

Male genitalia without parameres. Penis does not significantly attain the apex of urocoxites IX (Fig. 3E). Ratio of lengths of apical and basal divisions of penis about 1.12.

Differential diagnosis. Machilinus petrophilus sp. nov. belongs to the subgenus Machilinus s. str. with $1+1$ eversible vesicles on urocoxites II-VII, and urostyli with apical spines (STURM \& BACH DE RocA 1992). This subgenus includes 21 described species, one of them with 3 subspecies. The bristletails of this subgenus on the structure of the male maxillary palpus can be divided into 4 groups: "rupestris", the $2^{\text {nd }}$ and $3^{\text {rd }}$ articles of male maxillary palpus without ventral spines (Machilinus rupestris (Lucas, 1846); M. spinosus Bitsch, 1967; M. elharchai Bitsch, 1967;

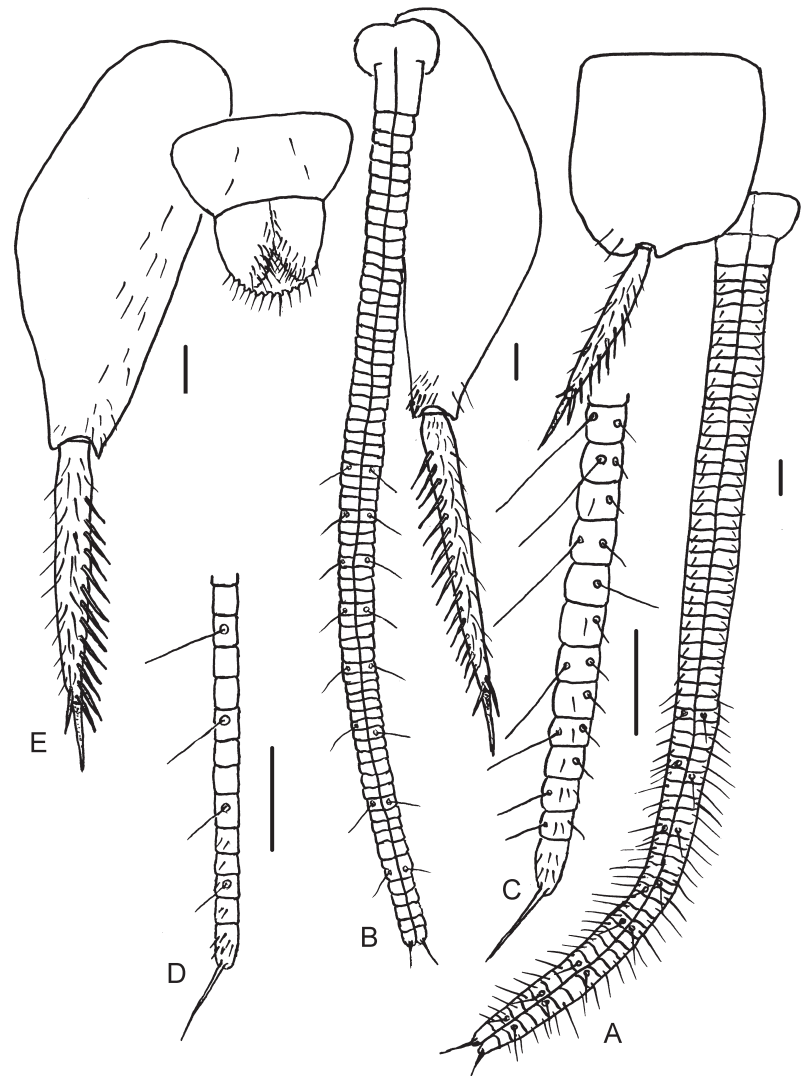

Fig. 3. Machilinus petrophilus sp. nov. (E-male, holotype; A-D-female, paratype): A - urocoxite VIII, with anterior gonapophyses; B - urocoxite IX, with posterior gonapophyses; $\mathrm{C}$-distal part of anterior gonapophysis; D - distal part of posterior gonapophysis; E - urocoxite IX, with penis. Scale bar: $0.1 \mathrm{~mm}$.

M. casasecai Bach, 1974; M. rosaliae Mendes, 1977; M. portosantensis Mendes, 1981; M. botellai Gaju-Ricart, Bach de Roca \& Molero-Baltanas, 1992; M. costai NotarioMuñoz, Bach de Roca \& Gaju-Ricart, 2000; M. caucasicus Kaplin, 2007; M. obscurus sp. nov.); "kleinenbergi", the $3^{\text {rd }}$ article of the male maxillary palpus with ventral spines which are missing on the $2^{\text {nd }}$ article; "rocai", the $2^{\text {nd }}$ and $3^{\text {rd }}$ articles of the male maxillary palpus with ventral spines (M. rocai Bach-Piella, 1975); "suttropi", the $2^{\text {nd }}$ article of the male maxillary palpus with ventral spines which are missing on the $3^{\text {rd }}$ article (M. suttropi Sturm, 2002). The $2^{\text {nd }}$ group "kleinenbergi" includes 9 described species, which can be divided into two subgroups: "helicopalpus" (M. cisatlanticus Janetschek, 1953; M. helicopalpus Janetschek, 1954; M. gredosi Bach, 1971; M. valencianicus Mendes \& Bach de Roca, 1981) with a very apparent swelling on the ventral side of the maxillary palpus and "bejarensis" (M. bejarensis Bach, 1971; M. kleinenbergi (Giardiana, 1900), redescribed by MENDES et al. 1981; M. spinifrontis Bach de Roca, 1984) with the $2^{\text {nd }}$ article of the male maxillary palpus without the very apparent swelling on the ventral side (JANETSCHEK 1953, 1954; BITSCH 1967; BACH Piella 1971, 1975; BACH DE Roca 1974, 1984; Mendes 1977, 1981; Mendes \& BaCH DE Roca 1981; GAJU-Ricart et al. 1992; NotARio-MuÑoz et al. 
2000; STURM 2002; KAPLIN 2007). The new species with black, relatively short and strong spines on the $3^{\text {rd }}$ and $2^{\text {nd }}$ articles of the male maxillary palpus are closest to $M$. rocai . Other species with these spines on the $3^{\text {rd }}$ and $2^{\text {nd }}$ articles of the male maxillary palpus are not described in the genus Machilinus. Distal chains of flagellum are divided into 8-9 annuli in Machilinus petrophilus sp. nov. and into 8 annuli in M. rocai. The main morphological differences between M. petrophilus sp. nov. and M. rocai are as follows. The color of compound eyes is uniform in $M$. rocai, and light gray with brown speckles in $M$. petrophilus sp. nov. Ratio of length to width of compound eye is 1.3-1.4 in M. petrophilus sp. nov. and 0.9-1.0 in $M$. rocai. Paired ocelli are 1.5 times as wide as long in male and 1.4 times in female of $M$. petrophilus sp. nov., and about 3.0 times in male of $M$. rocai. Clypeus of the male and female of $M$. petrophilus sp. nov. bears numerous short chaetae that are missing from the clypeus of both sexes of $M$. rocai. The lateral apophysis of the $2^{\text {nd }}$ article of the male maxillary palpus reaches far beyond the top of this article in M. petrophilus sp. nov., but it does not significantly reach the top of the $2^{\text {nd }}$ article of the male maxillary palpus in $M$. rocai. Number of spines on the hind tibia of $M$. petrophilus sp. nov. and $M$. rocai is 24-25 in male and 21 in female, and 22 in male and 11 in female, respectively. Apical article of male labial palpus is without sexual dimorphism in M. petrophilus sp. nov. and with it in M. rocai.

Etymology. The species name petrophilus is a latinized Greek adjective meaning "loving petrophytic deposits," referring to the predominant habitat type (Fig. 8).

Habitats. Scree of lime marl on the slope of the ravine. Petrophytic steppe communities with dominance of Thymus cretaceus Klokov \& Des.-Shost., Artemisia hololeuca M. Bieb. ex Besser, Onosma tanaitica Klokov, Linum czernjavii Klokov, Koeleria gracilis Pers., and Jurinea brachycephala Klokov (Fig. 8).

\section{Machilinus obscurus Kaplin, sp. nov.} (Figs 4, 5)

Type material. HoLOTYPE: $\widehat{\alpha}$ (slide-mounted, ZIN), UKRAINE: Donetsk region, near Starobeshevo, $47^{\circ} 45^{\prime} 01^{\prime \prime} \mathrm{N}, 38^{\circ} 01^{\prime} 45^{\prime \prime} \mathrm{E}, 140 \mathrm{~m}$ a.s.l., rock outcrops, stony steppe, under stones, July 22, 2019, V. Martynov leg. Paratypes: 5 (one on slides), 20 , the same locality, V. Martynov leg. (ZIN).

Description. Body length: male $6.8-6.9 \mathrm{~mm}$, female $7.2-7.8 \mathrm{~mm}$. Body width: male $2.0-2.2 \mathrm{~mm}$, female 2.2-2.3 mm. Antennal length: $4.5 \mathrm{~mm}$ in male, $3.7-4.3$ $\mathrm{mm}$ in female (broken); cercal length $2.2-2.3 \mathrm{~mm}$ in male, 2.7-3.0 $\mathrm{mm}$ in female; total eyes width: $0.76-0.84 \mathrm{~mm}$ in male, $0.81-0.87 \mathrm{~mm}$ in female; eye length: $0.48-0.53$ $\mathrm{mm}$ in male, $0.50-0.53 \mathrm{~mm}$ in female; paired ocelli width: $0.17-0.21 \mathrm{~mm}$ in both sexes; paired ocelli length: $0.11-0.13 \mathrm{~mm}$ in both sexes. Ovipositor length 3.0-3.3 $\mathrm{mm}$. Thoracic coxal styli absent. Head including antennae, maxillary and labial palpi, clypeus, labrum, labium, and legs without scales.

General body color light yellow or whitish, with purple -brown hypodermal pigment of medium intensity. Color of body scales mostly brown and dark brown. Antennae in
Table 5. Ratios of lengths to widths of main leg articles in Machilinus obscurus sp. nov.

\begin{tabular}{llcc}
\hline \multirow{2}{*}{ Leg articles } & \multicolumn{2}{c}{ Sex } \\
\cline { 3 - 4 } Tarsus & Male & Female \\
& middle & 5.40 & $4.80-4.92$ \\
& hind & $4.95-5.00$ & $4.72-4.79$ \\
\hline \multirow{2}{*}{ Tibia } & fore & $5.73-5.77$ & 6.89 \\
& middle & 2.23 & 2.12 \\
& hind & $2.30-2.42$ & $2.21-2.28$ \\
\multirow{3}{*}{ Femur } & fore & $3.73-3.75$ & 3.47 \\
& middle & 1.94 & $1.92-1.94$ \\
& hind & $2.92-3.00$ & 2.76 \\
\multirow{2}{*}{ Coxa } & fore & $3.02-3.11$ & 2.55 \\
& middle & 2.40 & $2.60-2.72$ \\
& hind & $2.64-2.66$ & $2.51-2.54$ \\
\hline
\end{tabular}

Table 6. Number of spines on legs in Machilinus obscurus sp. nov.

\begin{tabular}{|c|c|c|c|c|c|c|c|}
\hline \multirow{3}{*}{ Segments } & & \multicolumn{6}{|c|}{ Sex and pair of legs } \\
\hline & & \multicolumn{3}{|c|}{ Male } & \multicolumn{3}{|c|}{ Female } \\
\hline & & fore & middle & hind & fore & middle & hind \\
\hline \multirow{3}{*}{ Tarsomeres } & $1^{\text {st }}$ & 7 & $6-8$ & $10-11$ & $4-5$ & $7-9$ & 8 \\
\hline & $2^{\text {nd }}$ & 10 & 10 & $11-12$ & 11 & 10 & 10 \\
\hline & $3^{\text {rd }}$ & 8 & $8-9$ & 8 & 9 & 7 & 9 \\
\hline Tibia & & 6 & $10-11$ & $18-19$ & $8-9$ & $10-12$ & $19-21$ \\
\hline Femur & & 10 & $14-15$ & 10 & $7-8$ & $13-14$ & $10-12$ \\
\hline
\end{tabular}

Table 7. Ratios of lengths of some abdominal structures in Machilinus obscurus sp. nov. Apical spines are not included in stylus length.

\begin{tabular}{|c|c|c|c|c|c|c|c|c|}
\hline \multirow[t]{2}{*}{ Urites } & \multicolumn{2}{|c|}{$\begin{array}{l}\text { Urosternite / } \\
\text { urocoxite }\end{array}$} & \multicolumn{2}{|c|}{$\begin{array}{l}\text { Stylus / } \\
\text { urocoxite }\end{array}$} & \multicolumn{2}{|c|}{$\begin{array}{l}\text { Apical spine } \\
\text { / stylus }\end{array}$} & \multicolumn{2}{|c|}{$\begin{array}{l}\text { Posterior angle } \\
\text { of urosternite }\end{array}$} \\
\hline & male & female & male & female & male & female & male & female \\
\hline$\overline{\text { II }}$ & 0.20 & 0.19 & 0.61 & 0.66 & 0.35 & 0.36 & $132^{\circ}$ & $132^{\circ}$ \\
\hline III & 0.21 & 0.19 & 0.59 & 0.65 & 0.35 & 0.36 & $142^{\circ}$ & $134^{\circ}$ \\
\hline IV & 0.19 & 0.18 & 0.56 & 0.61 & 0.35 & 0.37 & $147^{\circ}$ & $147^{\circ}$ \\
\hline V & 0.15 & 0.15 & 0.49 & 0.55 & 0.42 & 0.42 & $158^{\circ}$ & $158^{\circ}$ \\
\hline VI & 0.14 & 0.15 & 0.50 & 0.56 & 0.36 & 0.41 & $162^{\circ}$ & $158^{\circ}$ \\
\hline VII & 0.12 & 0.12 & 0.54 & 0.55 & 0.36 & 0.41 & $153^{\circ}$ & $160^{\circ}$ \\
\hline VIII & 0.11 & - & 0.63 & 0.83 & 0.34 & 0.36 & $164^{\circ}$ & - \\
\hline IX & - & - & 0.64 & 0.72 & 0.23 & 0.25 & - & - \\
\hline
\end{tabular}

Table 8. Distribution of sublateral mesochaetae and relatively thin chaetae on urocoxites in Machilinus obscurus sp. nov.

\begin{tabular}{lcc}
\hline \multirow{2}{*}{ Urites } & \multicolumn{2}{c}{ Urocoxites } \\
\cline { 2 - 3 } & Male & Female \\
\hline II & $(16-17+16-17)$ & $\approx(26-27+26-27)$ \\
III & $13-14+13-14$ & $\approx(22-23+22-23)$ \\
IV & $7+7$ & $\approx(18-19+18-19)$ \\
V & $6-7+6-7$ & $12-14+12-14$ \\
VI & $4-5+4-5$ & $8+8$ \\
VII & $1+1$ & $5-6+5-6$ \\
VIII & 0 & $3+3$ \\
IX & $0 / 8+9 / 0$ & $0 /(9 *+8)+(9 *+11) / 0$ \\
\hline
\end{tabular}

* Relatively short pigmented macrochaetae.

both sexes shorter than body. Ratio of length to width of scapus about 2.0 in male and 2.2 in female (Fig. 4A). Dorsal surface of scapus and pedicellus with slightly pigmented simple chaetae. Several of these chaetae on basal part of scapus smaller and colorless. Distal chains of flagellum divided into eight annuli in both sexes. Two or three distal chains of antennal flagellum broken. Frons and clypeus of male with relatively numerous short simple chaetae (Fig. 4B). Cercus approximately $0.32-0.33$ times as long as body length in male and $0.35-0.40$ times in female. Cerci with 18-20 articles in male and 22-24 in female. Articles of cerci, except for apical one or two, with 1-3 supporting 


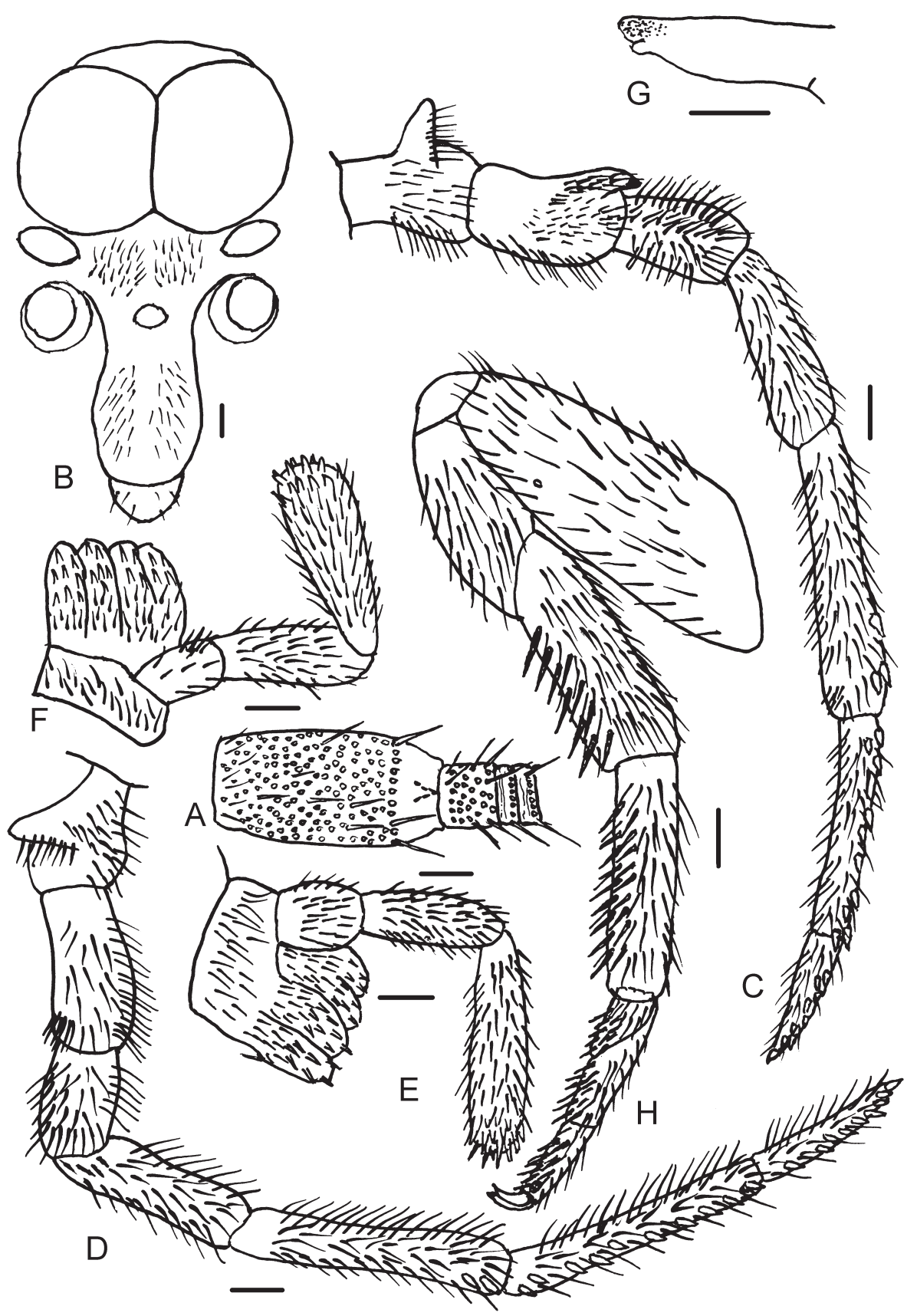

Fig. 4. Machilinus obscurus sp. nov. (A-C, F, G, H - male, holotype; D, E - female, paratype): A - scapus, pedicellus and two basal annuli of flagellum; B - head, front view; C, D - maxillary palpus; E, F - labial palpus and labium (part); G - distal part of mandible; H - hind leg. Scale bar: $0.1 \mathrm{~mm}$.

spines on inner side. Cerci and caudal filament also with long chaetae.

Compound eyes unicolorous, dark or almost black (in ethanol). Ratio of length to width of compound eye about $1.2-1.3$ in both sexes; ratio of contact line length to eye length $0.66-0.70$ in both sexes. Paired ocelli oval, sublateral, white; 1.7 times as wide as long in male and 1.5-1.6 times in female (Fig. 4B). Distance between inner margins of ocelli $0.56-0.58$ and between their outer margins 0.96 0.98 times total width of compound eye, in both sexes.

Apical article of maxillary palpus of male $0.54-0.56$ and female $0.58-0.60$ times as long as preceding one. Dorsal surface of $7^{\text {th }}, 6^{\text {th }}$ and $5^{\text {th }}$ articles of maxillary palpus with 8 or 9,10 or 11 , and 3 hyaline spines in male, and 9,11 and 2 spines in female, respectively. $5^{\text {th }}$ article of maxillary palpus $1.48-1.50$ times as long as $4^{\text {th }}$ article in male and 1.43-1.47 times in female (Figs 4C, D). Second article of male maxillary palpus noticeably curved with external lateral apical apophysis, which is absent in female maxillary palpus. Apophysis surpassing distal end of $2^{\text {nd }}$ article. Outer side of apophysis with about 15 dark lateral chaetae and several longer simple chaetae in upper part of apophysis, without ventral spiniform chaetae. $3^{\text {rd }}$ article of male maxillary palpus with numerous dark brown relatively long thick chaetae, without ventral spines. Apical article of labial palpus triangularly oval, 2.9 times as long as wide in male and 3.7 times in female (Figs 4E, F). Mandibles in both sexes with two teeth (Fig. 4G). 


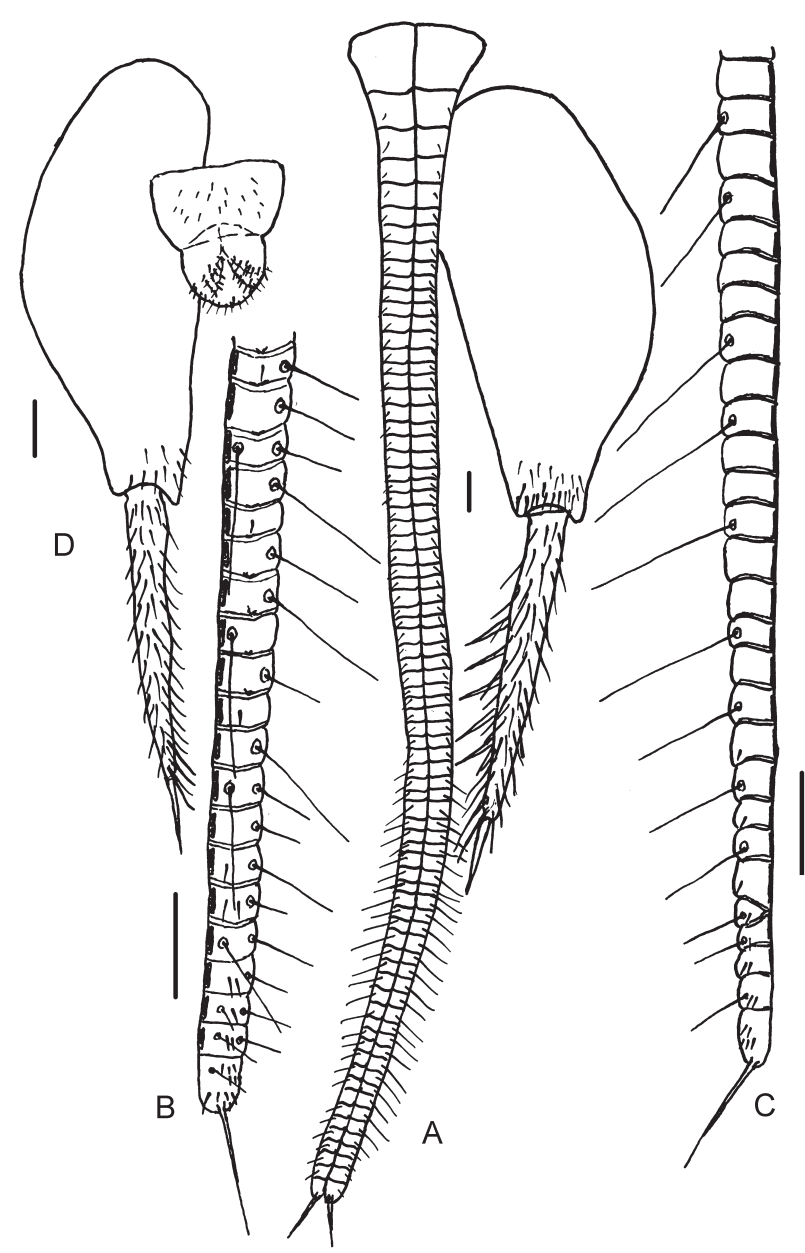

Fig. 5. Machilinus obscurus sp. nov. (D-male, holotype; A-C - female, paratype): A - urocoxite IX, with anterior gonapophysis; B - distal part of anterior gonapophyses; C - distal part of posterior gonapophysis; D - urocoxite IX, with penis. Scale bar: $0.1 \mathrm{~mm}$.

Fore femur and tibia widened in both sexes. Ratios of lengths to widths of coxa, femur, tibia, and tarsus as shown in Table 5. Ratio of length of $3^{\text {rd }}$ tarsomere to total length of tarsus $0.40-0.41$ in male and $0.37-0.38$ in female (Fig. 4H). Legs of male without long thin chaetae. Ventral surface of femora, tibiae and tarsi with spine-like chaetae as shown in Table 6. Pretarsi with well-developed conical strongly pigmented support protrusion as in M. petrophilus sp. nov. (Fig. 1K).

In both sexes, abdominal segments II-VII with $1+1$ eversible vesicles. Posterior angle of urosternites more than $130^{\circ}$ (Table 7). Ratio of lengths of urosternite and urocoxite I in male about 0.29 . Ratios of lengths of urosternite, urocoxite and stylus (without apical spine) on urites II-IX as shown in Table 7. Inner posterior lobes of urocoxites VII of female protruding; ratio of length to their total width about 0.45 .

Inner margins of its lateral expansions with about 20-22 $+20-22$ macrochaetae in both sexes. Lateral margins of mesonotum with 60-65+60-65, metanotum with 20-22+ 20-22 macrochaetae in both sexes. Lateral parts of pronotum with 20-22 thin chaetae in male and 15-18 in female, those of mesonotum with 95-105 in both sexes, those of metanotum with 55-60 + 55-60 in male and 4-5 + 4-5 in female. Anterior part of urotergite I with 10-12 + 10-12 sublateral chaetae as in M. petrophilus (Fig. 2E), urotergites II-VIII and X without chaetae, urotergite IX with $1+1$ mesochaetae in both sexes. Anterior part of urocoxites I with about $18+18$ chaetae in both sexes. Distribution of sublateral chaetae on urocoxites II-IX as shown in Table 8.

Ovipositor slender, elongate, extending much further than apex of styli IX (Fig. 5A). Anterior and posterior gonapophyses with 77 and 79 articles, respectively. One basal division of anterior gonapophyses and about 52 proximal divisions of posterior gonapophyses glabrous. Distal divisions of anterior and posterior gonapophyses with 5 , and 9 or 10 chaetae, respectively (not counting sensory setae and apical spines) (Figs 5B, C). About 37 distal divisions of anterior gonapophyses and 28 distal divisions of posterior gonapophyses with long setae. Apical spines of gonapophyses as long as about 3.3 distal divisions combined.

Male genitalia without parameres. Penis does not significantly attain the apex of urocoxites IX, ratio of distance between apexes of penis and urocoxites IX to width of apical article of penis about 2.4 (Fig. 5D). Ratio of lengths of apical and basal articles of penis about 1.0.

Differential diagnosis. Machilinus obscurus sp. nov. belongs to the group "rupestris" with 10 described species that do not possess spines on the $3^{\text {rd }}$ and $2^{\text {nd }}$ articles of the maxillary palpus in the male (Mendes 1977, NoTARIO-MunOz et al 2000). Among them, M. rupestris Silvestri, 1904 has 3 subspecies. The main morphological differences between $M$. obscurus sp. nov. and its closest congeners are shown in Table 9. Only the compound eyes of $M$. obscurus sp. nov. are uniformly dark and almost black. Forehead and clypeus of Machilinus obscurus sp. nov. and M. spinosus bear numerous short chaetae but these species are easily distinguished by the color of the compound eyes, the ratio of length to width of the eye, eye contact line length and other features. $5^{\text {th }}$ article of the male maxillary palpus of M. botellai and M. casasecai bears numerous long thin chaetae which are absent in the new species and other species of this group (ВАCH 1974, GAJU et al. 1992). M. obscurus sp. nov. is similar to $M$. rosaliae in number of spines on legs, ratio of length of apical article of labial palpus to its width in the male compared to the female, numerous small chaetae on clypeus, ratio of lengths of apical and preapical articles of maxillary palpus and ratio of length to width of compound eye. Machilinus rosaliae differs from the new species in the color of compound eyes, ratio of lengths of contact line and eyes, in the absence of numerous small chaetae on frons (Table 9). The apical article of the male labial palpus of $M$. rosaliae displays sexual dimorphism. The apophysis does not surpass the distal end of the $2^{\text {nd }}$ article (Mendes 1977).

Etymology. The species name obscurus is a Latin adjective meaning dark, referring to the predominant color of the body scales.

Habitats. Outputs of Upper Carboniferous limestones in the Kalmius River valley. Petrophytic steppe communities 
Table 9. The main morphological differences between Machilinus obscurus sp. nov. and its closest congeners (after BITSCH 1967; BACH DE RoCA 1974; Notario-Muñoz et al. 2000; Mendes 1977, 1981; KAPLIN 2007).

\begin{tabular}{|c|c|c|c|c|c|c|c|c|c|c|c|}
\hline \multicolumn{2}{|l|}{$\begin{array}{l}\text { Mophological } \\
\text { characters }\end{array}$} & 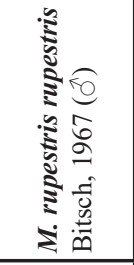 & 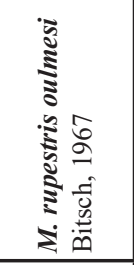 & 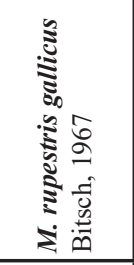 & 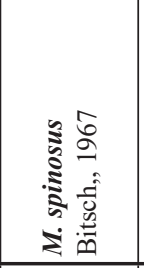 & 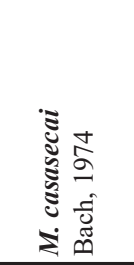 & 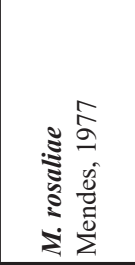 & 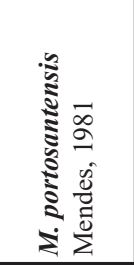 & 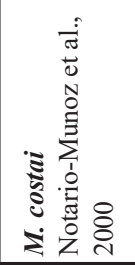 & 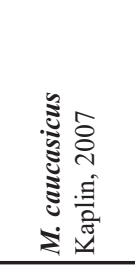 & 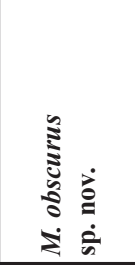 \\
\hline \multicolumn{2}{|c|}{$\begin{array}{l}\text { Color of } \\
\text { compound eyes }\end{array}$} & dark grey & $\begin{array}{l}\text { light with } \\
\text { small } \\
\text { brown-red } \\
\text { spots }\end{array}$ & $?$ & \begin{tabular}{|c|} 
light with \\
oblique \\
incomplete \\
pigmented \\
strip
\end{tabular} & $\begin{array}{l}\text { lightwith } \\
\text { brown } \\
\text { spots } \\
\text { and two } \\
\text { oblique } \\
\text { lines }\end{array}$ & $\begin{array}{c}\text { yellowish } \\
\text { or reddish } \\
\text { with dar- } \\
\text { ker diffuse } \\
\text { spots }\end{array}$ & $\begin{array}{l}\text { very dark, } \\
\text { lighter in } \\
\text { the inner } \\
\text { part }\end{array}$ & $?$ & $\begin{array}{l}\text { dark with } \\
\text { a bluish } \\
\text { tinge } \\
\text { and faint } \\
\text { brown } \\
\text { spots }\end{array}$ & $\begin{array}{l}\text { dark or } \\
\text { almost } \\
\text { black }\end{array}$ \\
\hline \multicolumn{2}{|c|}{$\begin{array}{l}\text { Ratio of length to } \\
\text { width of compound eye }\end{array}$} & $1.07-1.09$ & $1.2-1.3$ & 1.3 & 1.0 & 1.0 & $1.1-1.3$ & 1.0 & $0.9-1.0$ & $1.3-1.4$ & $1.2-1.3$ \\
\hline \multicolumn{2}{|c|}{$\begin{array}{l}\text { Ratio of contact line } \\
\text { length to length of eyes }\end{array}$} & $0.48-0.56$ & 0.65 & $0.66-0.75$ & $0.51-0.56$ & $0.79-0.80$ & $0.8-0.9$ & $0.6-0.7$ & $0.50-0.63$ & $0.66-0.72$ & $0.66-0.70$ \\
\hline \multicolumn{2}{|c|}{$\begin{array}{l}\text { Ratio of lengths of } \\
\text { apical and preapical } \\
\text { articles of maxillary } \\
\text { palpus }\end{array}$} & 0.57 & $\begin{array}{l}0.60- \\
0.67 \lesssim\end{array}$ & $0.52 \AA$ & $\begin{array}{l}0.45 \hat{\sigma} \\
0.50 \text { ㅇ }\end{array}$ & $\begin{array}{l}0.45 \hat{\jmath} \\
0.62 \%\end{array}$ & $0.5-0.6$ & $0.60-0.65$ & $\begin{array}{l}0.67 \AA \\
0.60 \%\end{array}$ & $0.60-0.65$ & $\begin{array}{l}0.54-0.56 \hat{\jmath}, \\
0.58-0.60 \text { ○ }\end{array}$ \\
\hline \multicolumn{2}{|c|}{$\begin{array}{l}\text { Ratio of length of apical } \\
\text { article of labial palpus to } \\
\text { its width }\end{array}$} & 2.9 & $2.8 \hat{0}$ & $3.3 \hat{\delta}$ & $\begin{array}{l}5.0 \hat{\partial} \\
3.0 \stackrel{1}{+}\end{array}$ & $\begin{array}{l}2.8 \hat{\jmath} \\
3.0 \stackrel{0}{+}\end{array}$ & $\begin{array}{l}2.3 \hat{3} \\
2.7 \stackrel{9}{+}\end{array}$ & $2.2-2.3$ & $\begin{array}{l}2.0 \hat{8} \\
2.4 \stackrel{+}{+}\end{array}$ & $2.9-3.0$ & $\begin{array}{l}2.9 \hat{O} \\
3.7 \%\end{array}$ \\
\hline \multicolumn{2}{|c|}{$\begin{array}{l}\text { Number of spines on the } \\
2^{\text {nd }} \text { article of hind leg }\end{array}$} & 6 & $6-8$ & 7 & $10-13$ & $7-12$ & $11-12$ & 7 & $6-9$ & $9-11$ & $10-12$ \\
\hline \multicolumn{2}{|c|}{$\begin{array}{l}\text { Number of spines on } \\
\text { hind tibia }\end{array}$} & $7-14$ & 7 & 12 & 13 & 16 & $19-29$ & $6-8$ & $11-23$ & $11-17$ & $18-21$ \\
\hline \multirow{3}{*}{$\begin{array}{l}\text { Ratio of } \\
\text { lengths } \\
\text { of stylus and } \\
\text { urocoxite }\end{array}$} & $\mathrm{V}$ & $0.38-0.43$ & $0.33-0.44$ & $0.68-0.80$ & $0.40-0.41$ & $0.39-0.40$ & $\begin{array}{l}0.5 \AA \\
0.39 \\
\end{array}$ & 0.4 & 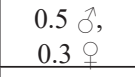 & 0.5 & 0.5 \\
\hline & VIII & 0.54 & $0.50-0.60$ & $\begin{array}{c}0.83 \hat{\jmath} \\
1.0 ?\end{array}$ & $0.52-0.60$ & $0.69-0.75$ & $\begin{array}{c}0.6-0.7 \AA \\
0.8 q\end{array}$ & $\begin{array}{l}0.6 \stackrel{1}{\rho} \\
0.7 \stackrel{0}{7} \\
\end{array}$ & 0.5 & $0.6-0.7$ & $\begin{array}{l}0.6 \hat{\jmath} \\
0.89\end{array}$ \\
\hline & IX & 0.53 & $0.49-0.57$ & $\begin{array}{l}0.9 \AA \\
0.7 \stackrel{9}{9} \\
\end{array}$ & $0.48-0.50$ & $0.47-0.53$ & $\begin{array}{c}0.6 \curvearrowright \\
0.59 \\
\end{array}$ & 0.6 & 0.4 & $0.6-0.7$ & 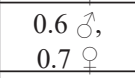 \\
\hline \multicolumn{2}{|c|}{$\begin{array}{l}\text { Numerous small } \\
\text { chaetae on head } \\
\text { of male }\end{array}$} & - & - & - & $\begin{array}{l}\text { on frons } \\
\text { and cly- } \\
\text { peus }\end{array}$ & $\begin{array}{l}\text { scattered } \\
\text { on the } \\
\text { lower part } \\
\text { of clypeus } \\
\end{array}$ & on clypeus & - & - & on clypeus & $\begin{array}{l}\text { on frons } \\
\text { and cly- } \\
\text { peus }\end{array}$ \\
\hline \multicolumn{2}{|l|}{ Distribution } & Algeria & Morocco & $\begin{array}{l}\text { Portugal, } \\
\text { Spain, } \\
\text { France }\end{array}$ & Morocco & Spain & Portugal & Madeira & Spain & $\begin{array}{c}\text { Russia } \\
\text { (Krasno- } \\
\text { dar region) } \\
\end{array}$ & Ukraine \\
\hline
\end{tabular}

with dominance of Stipa lessingiana Trin. \& Rupr., S. grafiana Steven, Thymus dimorphus Klokov \& Des.-Shost., T. calcareus Klokov \& Des.-Shost., Ephedra distachya L., Koeleria brevis Steven., Ulmus glabra Huds., Prunua stepposa Kotov., Spiraea hypericifolia L., Caragana scythica (Kom.) Pojark., Convolvulus lineatus L., and Rosa subpygmaea Chrshan. (Fig. 9).

\section{Family Machilidae}

\section{Charimachilis rostoviensis Kaplin, sp. nov. (Figs 6, 7)}

Type material. HоLотуре: $q$ (slide-mounted, ZIN), RUSSIA: Rostov-on-Don, Botanical garden of the Southern Federal University, $47^{\circ} 14^{\prime} 13^{\prime \prime} \mathrm{N}, 39^{\circ} 39^{\prime} 12^{\prime \prime} \mathrm{E}, 50 \mathrm{~m}$ a.s.l., under a dead pine trunk, June 19 , 2019, V. Martynov leg. PARATYPEs: 3 ++ (one on slide), 6 juv., the same locality, V. Martynov leg. (ZIN).

Description. Female. Body length $9.6-11.0 \mathrm{~mm}$; body width $2.8-3.1 \mathrm{~mm}$; antennal length $5.8-6.8 \mathrm{~mm}$; cercal length $4.1-4.4 \mathrm{~mm}$; total eyes width $1.00-1.03 \mathrm{~mm}$, eye length $0.42-0.44 \mathrm{~mm}$; paired ocelli width $0.50-0.51 \mathrm{~mm}$, length $0.18-0.19 \mathrm{~mm}$. Coxal styli length $0.62-0.65 \mathrm{~mm}$. Ovipositor length 1.4-1.6 mm.

General body color whitish, with brown hypodermal pigment of faint or medium intensity only on antennal base, frons, gena, lateral sides of clypeus, mandible, galea of maxilla. Frons between eyes convex. Color of scales on upper and lower surface of body brown. Antennae shorter than body. Distal chains of flagellum divided into 8-12 annuli. Cercus $0.42-0.46$ times as long as body length, with about 21 divisions. Apex of cercus with one large lateral spike (Fig. 6A). Divisions of cerci, except for apical three, with 1-3 colorless supporting macrochaetae on inner side.

Compound eye color from dark brown to almost black with light gray tint in central part and near eye contact line. Ratio of length to width of compound eye about 0.86 ; ratio of contact line length to eye length $0.33-0.35$. Paired ocelli shoe-shaped, black with narrow white rim, located in front of eyes. Distance between inner margins of ocelli $0.08-0.10$ and between their outer margins $0.96-0.98$ total width of compound eyes (Fig. 6B). 


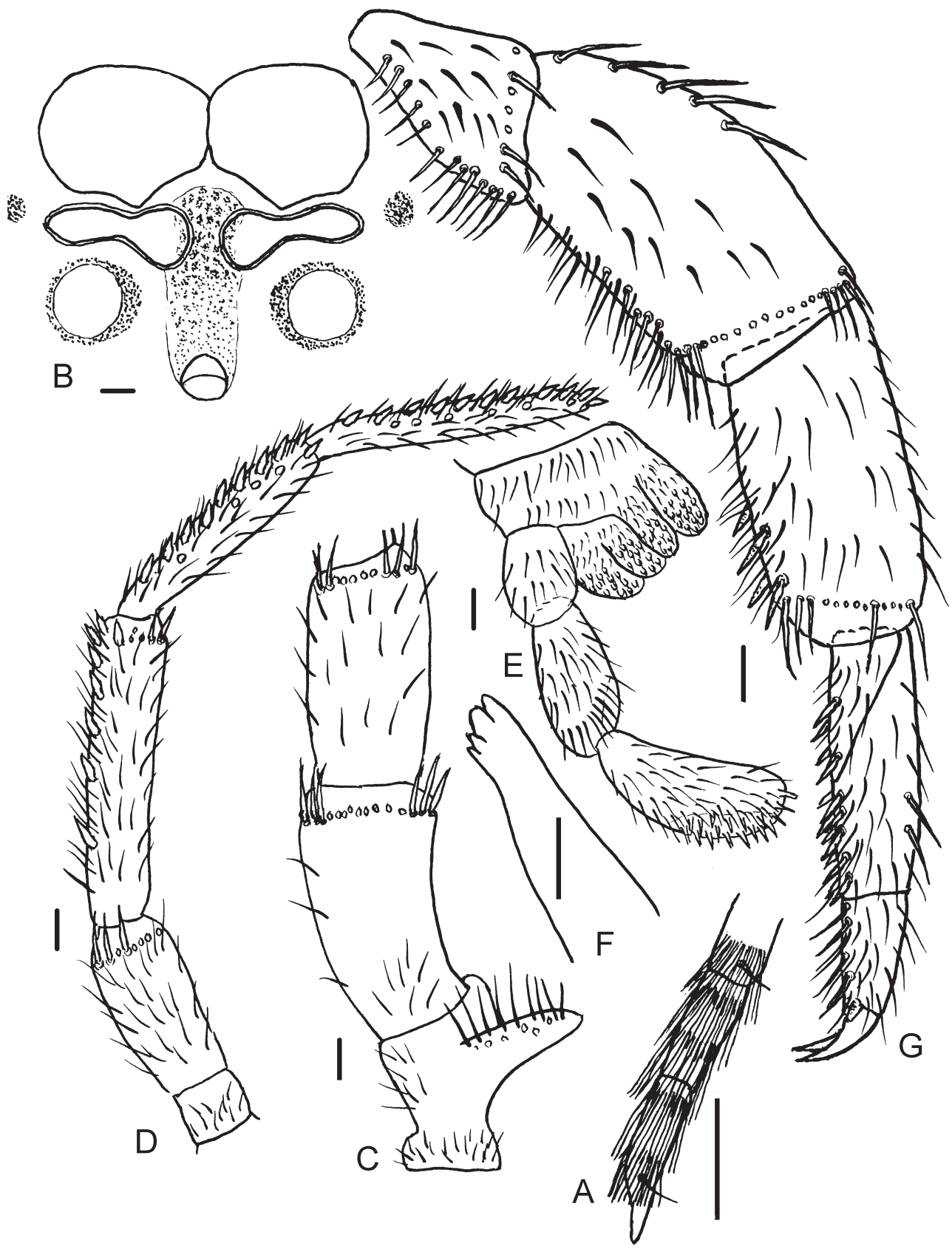

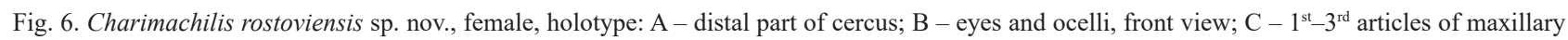
palpus; D $-4^{\text {th }}-7^{\text {th }}$ articles of maxillary palpus; $\mathrm{E}-$ labial palpus, with labium (part); F - distal part of mandible; $\mathrm{G}-$ part of fore leg. Scale bar: $0.1 \mathrm{~mm}$.

Table 10. Ratios of lengths to widths of main leg articles in Charimachilis rostoviensis $\mathrm{sp}$. nov.

\begin{tabular}{lccc}
\hline \multirow{2}{*}{ Leg articles } & \multicolumn{3}{c}{ Pair of legs } \\
\cline { 2 - 4 } & fore & middle & hind \\
\hline Tarsus & $4.28-4.33$ & $3.20-3.32$ & $4.21-4.27$ \\
Tibia & $2.06-2.15$ & $1.92-1.93$ & $2.75-2.81$ \\
Femur & $1.91-2.05$ & $1.98-1.99$ & $2.26-2.40$ \\
\hline
\end{tabular}

Table 11. Number of spines on legs in Charimachilis rostoviensis sp. nov.

\begin{tabular}{llccc}
\hline \multirow{2}{*}{ Segments } & & \multicolumn{3}{c}{ Pair of legs } \\
\cline { 3 - 5 } & & fore & middle & hind \\
\hline \multirow{3}{*}{ Tarsomeres } & $1^{\text {st }}$ & $7-8$ & 8 & $6-8$ \\
& $2^{\text {nd }}$ & 10 & 10 & $8-10$ \\
& $3^{\text {rd }}$ & 0 & 0 & 0 \\
\hline Tibia & & $3-4$ & 8 & $12-13$ \\
Femur & 0 & $1-2$ & $1-2$ \\
\hline
\end{tabular}

Table 12. Ratios of lengths of some abdominal structures and distribution of sublateral macrochaetae on urocoxites and urotergites in Charimachilis rostoviensis sp. nov. Stylus length does not include apical spines.

\begin{tabular}{lccccc}
\hline Urites & $\begin{array}{c}\text { Urosternite / } \\
\text { urocoxite }\end{array}$ & $\begin{array}{c}\text { Stylus / } \\
\text { urocoxite }\end{array}$ & $\begin{array}{c}\text { Apical } \\
\text { spine / } \\
\text { stylus }\end{array}$ & \multicolumn{2}{c}{$\begin{array}{c}\text { Number } \\
\text { of sublateral spines }\end{array}$} \\
\cline { 4 - 6 } & & & urocoxite & urotergite \\
\hline II-V & $0.72-0.75$ & $0.50-0.52$ & $0.42-0.49$ & 0 & 0 \\
V & 0.75 & 0.49 & 0.50 & 0 & $0-1+0-1$ \\
VI & 0.76 & 0.48 & 0.53 & 0 & $1+1$ \\
VII & 0.62 & 0.52 & 0.50 & $1+1$ & $2-3+2-3$ \\
VIII & - & 0.95 & 0.42 & $2-3+2-3$ & $2-3+2-3$ \\
IX & - & 0.46 & 0.40 & $1 / 6+6 / 1$ & $2+2$ \\
$\mathrm{X}$ & - & - & - & - & 0 \\
\hline
\end{tabular}




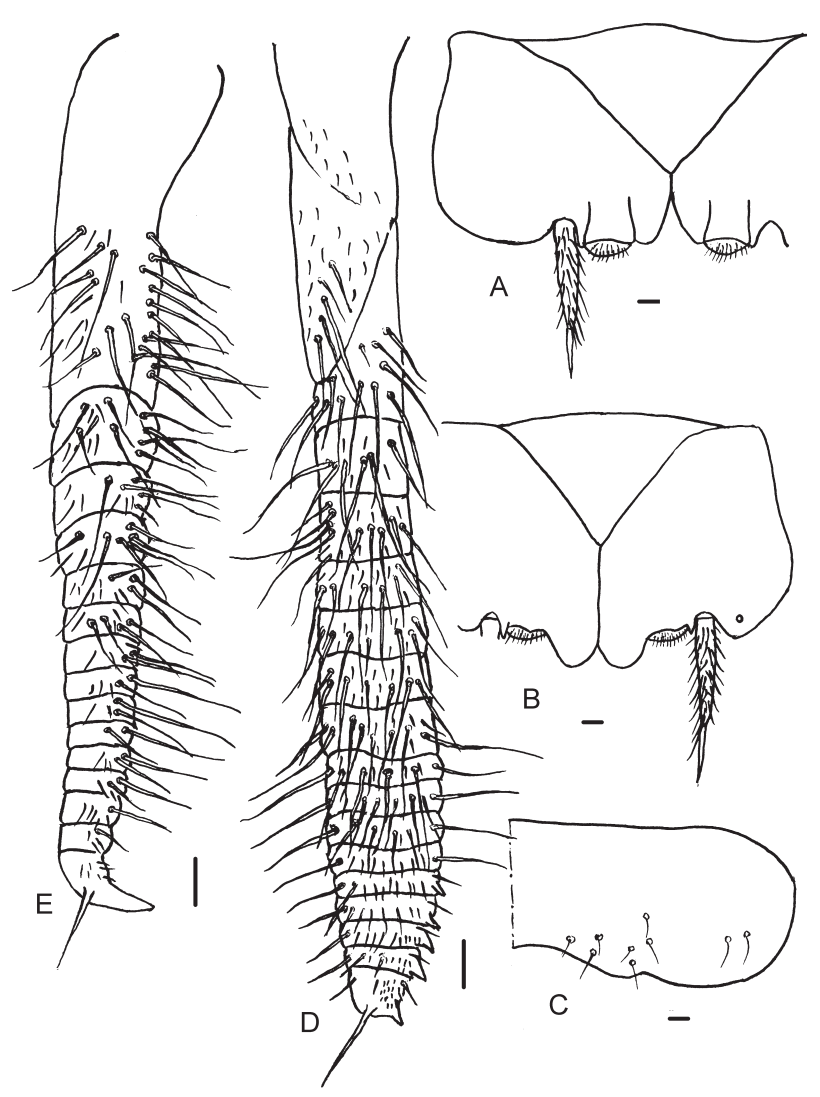

Fig. 7. Charimachilis rostoviensis sp. nov., female, holotype: A - urosternite and urocoxites V (part); B - urosternite and urocoxites VII (part); $\mathrm{C}$ - urotergite X (part); D - anterior gonapophysis; E-posterior gonapophysis. Scale bar: $0.1 \mathrm{~mm}$.

Apical article of maxillary palpus $1.12-1.14$ times as long as preceding one. Dorsal surface of $7^{\text {th }}, 6^{\text {th, }}$ and $5^{\text {th }}$ articles of maxillary palpus with 17, 13 or 14, and 8 or 9 hyaline spines, respectively (Figs 6C, D). Apical article of labial palpus triangularly oval, 2.3 or 2.4 times as long as wide (Fig. 6E). Mandibles with four distal teeth (Fig. 6F).

Fore and middle femur and tibia widened (Fig. 6G). Ratios of lengths to widths of femur, tibia and tarsus as shown in Table 10. Ratio of length of $3^{\text {rd }}$ tarsomere to total length of tarsus $0.30-0.31$. Ventral surface of femora, tibiae and tarsi with spine-like chaetae as shown in Table 11. Middle and hind legs with coxal styli. Ratio of styli length to width of middle and hind coxae about 1.7.

Abdominal segments I-VII with $1+1$ eversible vesicles (Figs 7A, B). Posterior angle of urosternites II-IV, $\mathrm{V}$, VI, and VII approximately $84-86^{\circ}, 79^{\circ}, 67^{\circ}$, and $77^{\circ}$, respectively. Ratios of lengths of urosternite, urocoxite and urostylus (without apical spine) II-IX as shown in Table 12.

Inner posterior lobes of urocoxites VII protruding (Fig. $7 \mathrm{~B}$ ); ratio of length to width of one lobe about 0.54 . Thoracic tergites, urotergites I-IV, urosternites, urocoxites I-VI without macrochaetae. Distribution of sublateral macrochaetae on other urocoxites and urotergites as shown in Table 12. Urocoxites IX with $1+1$ outer and $6+6$ inner sublateral spines. Urotergite $\mathrm{X}$ with small thin chaetae (Fig. 7C).

Ovipositor weakly sclerotized, thickened, completely concealed by urocoxites IX, typical of genus Charimachilis. Anterior and posterior gonapophyses with 17 and 15 divisions, respectively (Figs 7D, E). Ultimate division of anterior gonapophyses with preapical spine and 2 apical lateral projections, one of which is pointed and sclerotized. Apical spines as long as 2 or 3 apical divisions combined. Anterior gonapophyses with 4 or 5 lateral digging spikes. Posterior gonapophyses with well developed, sclerotized curved apical horn and preapical spine, as long as 2 apical divisions combined. Distribution of sensory and simple chaetae on divisions of anterior and posterior gonapophyses as in Figs 7D, E.

Male. Unknown. The species is probably parthenogenetic, similar to most its congeners.

Differential diagnosis. Genus Charimachilis Wygodzinsky, 1939 includes 13 described species (KaPLin 2019). Only females are known in 11 species. This makes it difficult to identify them. Charimachilis rostoviensis sp. nov. most closely resembles C. ukrainensis Stach, 1958 in ovipositor morphology. The main morphological differences between them are shown in Table 13. The posterior angle of urosternites is clearly acute (less than $75^{\circ}$ ) in $C$. rostoviensis sp. nov. and almost right $\left(79-86^{\circ}\right)$ in C. ukra-

Table 13. Differences between Chariumachilis rostoviensis sp. nov., Chariumachilis wahrmani Wygodzinsky, 1959, and Chariumachilis ukrainensis Stach, 1958.

\begin{tabular}{|c|c|c|c|}
\hline Morphological characters & C. rostoviensis sp. nov. & $\begin{array}{l}\text { C. ukrainensis } \\
\text { Stach, } 1958 \\
\end{array}$ & $\begin{array}{c}\text { C. wahrmani } \\
\text { Wygodzinsky, } 1959\end{array}$ \\
\hline Ratio of cercus length to body length & $0.42-0.47$ & 0.27 & ? \\
\hline Ratio of compound eye length to width & 0.86 & 0.82 & 0.9 \\
\hline Ratio of contact line length to eye length & $0.33-0.35$ & 0.40 & 0.45 \\
\hline $\begin{array}{l}\text { Ratio of distance between inner margins of ocelli to total width } \\
\text { of compound eyes }\end{array}$ & $0.08-0.10$ & $0.10-0.11$ & 0.17 \\
\hline $\begin{array}{l}\text { Ratio of lengths of apical article of maxillary palpus and the } \\
\text { preceding one }\end{array}$ & 1.1 & 1.2 & 1.1 \\
\hline Posterior angle of urosternites II-V & $50-70^{\circ}$ & $79-86^{\circ}$ & $<90^{\circ}$ \\
\hline \multirow{3}{*}{$\begin{array}{l}\text { Ratio of stylus length (without apical spines) } \\
\text { to urocoxite length }\end{array}$} & $0.48-0.53$ & $0.62-0.68$ & 0.4 \\
\hline & 0.95 & 0.9 & 0.55 \\
\hline & 0.46 & 0.75 & 0.45 \\
\hline Number of sublateral spines on urocoxite VIII & $2-3$ & $1-2$ & $?$ \\
\hline \multirow{2}{*}{ Number of sublateral spines on urocoxite IX } & 1 & 1 & 0 \\
\hline & 6 & $6-7$ & 3 \\
\hline \multirow{3}{*}{\begin{tabular}{ll}
\multirow{2}{*}{ Number of gonapophyses divisions } & VIII \\
\cline { 2 - 2 } & IX \\
Number of lateral digging spikes on anterior gonapophyses
\end{tabular}} & 17 & 15 & 15 \\
\hline & 15 & 17 & $12-13$ \\
\hline & $4-5$ & $3-4$ & $5-6$ \\
\hline
\end{tabular}



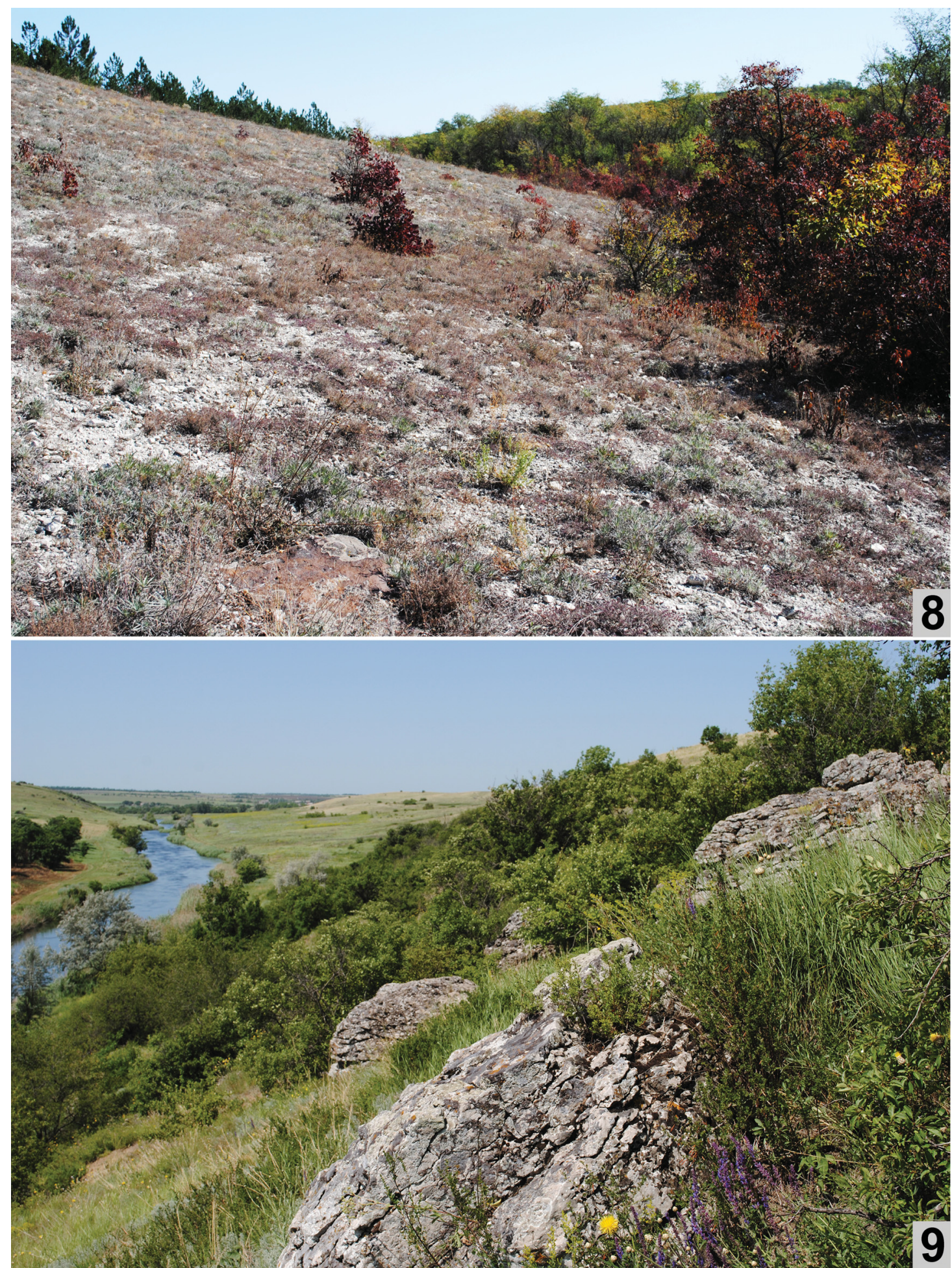

Figs 8-9. Habitats of the new species. 8 - habitat of Machilinus petrophilus sp. nov., Amvrosiivka, July 22, 2019. 9 - habitat of Machilinus obscurus sp. nov., Starobeshevo, right bank of the Kalmius river, September 24, 2019. (Photos by V. Martynov).

inensis from Ukraine. Ratio of cercus length to body length is about 0.3 in C. ukrainensis and more than 0.4 in $C$. rostoviensis sp. nov. Ratio of stylus length (apical spines excluded) to urocoxite II-VII is $0.6-0.7$ in C. ukrainensis and about 0.5 in $C$. rostoviensis sp. nov. C. rostoviensis sp. nov. is also similar to C. wahrmani Wygodzinsky, 1939 from Turkey in the structure to compound eye, maxillary palpus, urocoxite IX (WyGODZINSKY 1959). C. wahrmani differs from the new species in ratio of distance between the inner margins of ocelli to the total width of compound eyes, ratio of stylus length to urocoxite VIII, number of sublateral spines on urocoxite IX, and the structure of the anterior and posterior gonapophyses (Table 13).

Etymology. The species is named after Rostov-on-Don where it was collected; adjective.

Habitats. Old artificial stands of pine Pinus sylvestris L. with undergrowth of Acer tataricum L. in the valley of the Temnik River. Under a trunk of a fallen dead pine. 


\section{Acknowledgments}

We are grateful to the reviewers for reading and editing the article, as well as for valuable comments and suggestions during its preparation for publication.

\section{References}

BACH PIELLA C. 1971: Tisanuros de la fauna española. Nuevas especies de Machilidae halladas en la Cordillera Central. Publicaciones Instituto de Biologia Aplicada 51: 103-151.

BACH-PIELLA C. 1975: Nueva especie de Machilinus Silvestri, 1904, de la provincia de Barcelona (Thys., Machilida). EOS 49(1-4): 29-36.

BACH DE ROCA C. 1974: A machilida new to Spain: Machilinus casasecai n. sp. (Insecta: Apterygota). Pedobiologia 14: 273-278.

BACH DE ROCA C. 1984: Description of two new species of Microcoryphia in Spain: Machilinus spinifrontis n.sp. and Promesomachilis cazorlensis n. sp. Annales de la Société Royale Zoologique de Belgique 114(1): 21-33.

BITSCH J. 1967: Les espèces circum-méditerranéennes du genre Machilinus (Insecta Thysanura). Bulletin de la Société des Sciences Naturelles et Physiques du Maroc 47(1-2): 165-191.

GAJÚ RICART M., BACH DE ROCA C. \& MOLERO BALTANÁS B. R. 1992: Descripción de una nueva especie de Meinertellidae de España: Machilinus botellai n. sp. (Insecta: Apterygota). Actas do Congresso Iberico de Entomologia 5(2): 83-90.

JANETSCHEK H. 1953: Ein neuer Felsenspringer aus dem Atlas (Thysanura, Machilidae). Zoologischer Anzeiger 150: 128-133.

JANETSCHEK H. 1954: Über Felsenspringer der Mittelmeerländer (Thysanura, Machilidae). EOS 30(3-4): 163-314.

KAPLIN V. G. 1983: K faune schetinokhvostok (Thysanura) yuzhnogo poberezhya Krima. (To the fauna of bristletails (Thysanura) of the southern Black Sea coast of Crimea.) Vestnik Zoologii 1983(5): 15-20 (in Russian, English abstract).
KAPLIN V. G. 2007: To the fauna of bristletails of the families Meinertellidae and Machilidae (Thysanura) from Krasnodar Territory and Kazakhstan. Entomological Review 87(9): 1242-1255.

KAPLIN V. G. 2019: A review of the distribution and phylogenetic relationships of bristletails of the genus Charimachilis Wygodz. (Archaeognatha, Machilidae) with descriptions of larvae of Ch. caucasica Kapl. and of a new species from Belgorod Province. Entomological Review 99(1): 91-115.

MENDES L. F. 1977: Thysanoures du Portugal. III. Le genre Machilinus au Portugal. Description d'une nouvelle espèce. Nouvelle Revue d'Entomologie 7(1): 9-20.

MENDES L. F. 1981: Nova nota e descrição de tisanuros (Microcoryphia e Zygentoma: Apterygota) da Macaronésia. Arquivos do Museu Bocage, Série A 1(9): 143-164.

MENDES L. F. \& BACH DE ROCA C. 1981: Notes sur quelques Thysanoures (Microcoryphia et Zygentoma) de l'Europe méridionale. Arquivos do Museu Bocage, Série A 1(1): 1-16.

NOTARIO-MUÑOZ M. J., BACH DE ROCA C. \& GAJU-RICART M. 2000: Machilinus costai, a new species of Meinertellidae (Insecta, Microcoryphia) from Spain. Proceedings of Vth International Seminar on Apterygota, Cordoba 1998. Pedobiologia 44(3-4): 300-308.

STACH J. 1958: Two new species of the genus Charimachilis Wyg. (Thysanura, Machilidae). Acta Zoologica Cracoviensia 3(2): 49-66.

STURM H. 2002: Machilinus (M.) suttropi sp. n. (Meinertellidae, Machiloidea, Archaeognatha, Insecta), eine neue Felsenspringerart von der Insel Rhodos. Entomologische Mitteilungen aus dem Zoologischen Museum Hamburg 14(165): 1-5.

STURM H. \& BACH DE ROCA C. 1992: New American Meinertellidae (Archaeognatha, Machiloidea). Pan-Pacific Entomologist 68(3): 174-191.

WYGODZINSKY P. 1959: Beitrag zur Kenntnis der Machilida und Thysanura der Türkei. Opuscula Entomologica 24(1-2): 36-54. 